TRANSPORT

\section{All Stations to Heathrow}

THE best way of carrying passengers from Heathrow airport to the centre of London would be to extend the Piccadilly underground line from Hounslow West to the airport, according to a study group set up by the Ministry of Transport. The extension, which London Transport would be able to build by the mid 1970s, would be 3.5 miles long and might carry 17 million passengers a year by 1981. Alternative schemes for a British Rail link with Heathrow should be ruled out because they would cost up to twice as much as the estimated $\$ 19$ million for the underground link, the study group concludes in its report (Rail Links with Heathrow Airport, Part I; HMSO, London, $12 \frac{1}{2} \mathrm{p}$ ).

If, as London Transport claims, the Piccadilly line will be capable of absorbing the extra traffic, this choice will have several further advantages. Passengers would be dispersed easily into the underground network at interchange stations, whereas the proposals by British Rail for a ground level railway would involve bringing everybody to Victoria station and leaving them to find their own means of transport for the onward journey. Workers at Heathrow could also use the underground line because a station could be built in the airport maintenance area, and fewer existing buildings would need to be demolished if the line were to go under the ground.

The London Transport scheme is favoured by British European Airways and the British Overseas Airways Corporation, but the British Airports Authority, which runs Heathrow, would prefer a British Rail link because of its belief that conditions on the underground line would be too uncomfortable. In the early morning overcrowding might be serious, because arrivals of transatlantic flights would clash with the heavy commuter traffic which makes tube travel unpleasant enough as things are, Getting baggage out of the underground trains at each station might lead to cumulative delays, and in any event the journey would be quicker by the non-stop services that British Rail has proposed.

\section{SCHOOLS}

\section{Wooing Children to Science}

\section{by our Education Correspondent}

Encouraging more schoolchildren to opt for mathematics and for science subjects in the sixth form is a long-standing problern which has no easy solution. But this week the Joint Mathematical Council, the Royal Institute of Chemistry and the Institution of Chemical Engineers have published documents which might help to relieve the situation. On the one hand, the Joint Mathematical Council is concerned that mathematics teaching should be kept up to date and, on the other, the Royal Institute of Chemistry and the Institution of Chemical Engineers are concerned to improve the image of careers in chemistry.

The Joint Mathematical Council has published a statement on the present state of change in mathematics at secondary school level, in which it sets out the principles which underlie what it considers to be the best features of the new mathematics curricula.
The aim of the statement is to provide a basis for discussion of so-called "modern mathematics" teaching. One problem is to decide what aspects of mathematics to teach, and to relate school curricula to recent advances in mathematics. But perhaps the most pressing problem is how to keep mathematics teachers fully informed of developments in teaching methods. The most effective way, the statement says, is to provide more facilities for in-service training.

The council believes that centres should be established in several parts of Britain, to provide in-service training on a regional basis. Such a centre is already operating in Nottingham, where staff from the University of Nottingham and from local colleges of education go out to schools to explain the thinking behind new courses. This approach, the council believes, is more effective than providing standardized courses for serving teachers.

Looming large over the council's thinking are the proposals for changing sixth form curricula and examinations. The council particularly wants to be sure that the proposals will not hold back the mathematically gifted child, and that they will not aggravate the shortage of mathematics teachers. It has set up a working party to consider the implications of the proposals for mathematics teaching, and the council will consider a report from the working party when it meets next week.

Improving the standard of teaching might help to attract students to mathematics, but perhaps the most effective incentive is the prospect of an interesting and highly paid career. It is with this thought in mind that the Royal Institute of Chemistry and the Institution of Chemical Engineers have launched a pamphlet which tells of the advantages to be gained from a career in the chemical industry. The pamphlet is aimed at children aged between thirteen and fifteen who, under the present system of specialized courses, will be taking erucial decisions about their future cducation. The Royal Institute and the Institution of Chemical Engineers bclieve that the need to convert more people to chemistry is so pressing that there is no time to wait for changes in sixth form curricula to take effect.

\section{MEETINGS}

\section{Astronomers Meet af Brighton}

Thw Regency exuberances of Brighton will be echoing to talk of quasars and pulsars this summer. For the first time since 1925, the triennial general assembly of the International Astronomical Union is meeting in Britain, at Brighton and on the nearby campus of the University of Sussex. On the first and last days of the meeting, August 18 and 27, the administrative affairs of the union will be conducted, but the main business will be the meetings of the forty or so commissions into which astronomy has been successfully compartmentalized by the union. There should ke plenty to talk about.

Commission 15, for example, is eoncerned with the physics of comets, and the members will be keen to discuss what to make of the vast hydrogen clouds which surround comets Tago-Sato-Kosaka and Bennett. Then there is commission, 17, charged with lunar affuirs, which has its hands full with trying to perfect a system for naming lunar features. At the last 